AperTO - Archivio Istituzionale Open Access dell'Università di Torino

\title{
Crucial role of Flvcrla in the maintenance of intestinal heme homeostasis
}

\section{This is the author's manuscript}

Original Citation:

Availability:

This version is available http://hdl.handle.net/2318/1529059

since 2015-11-23T14:14:34Z

Published version:

DOI:10.1089/ars.2014.6216

Terms of use:

Open Access

Anyone can freely access the full text of works made available as "Open Access". Works made available under a Creative Commons license can be used according to the terms and conditions of said license. Use of all other works requires consent of the right holder (author or publisher) if not exempted from copyright protection by the applicable law. 


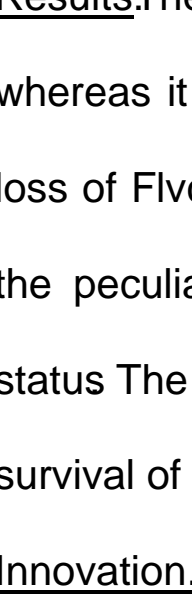





















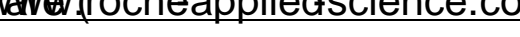






















